\title{
Empowerment of local government in New Zealand: a new model for contemporary local-central relations?
}

\author{
Commonwealth Journal of Local Governance \\ Issue 1: May 2008 \\ http://epress.lib.uts.edu.au/ojs/index.php/cjlg
}

\author{
Christine Cheyne ${ }^{1}$ \\ Massey University
}

\begin{abstract}
Since 2000 intergovernmental relations in New Zealand have been evolving rapidly as a result of a significant shift in government policy discourse towards a strong central-local government partnership. New statutory provisions empowering local government to promote social, economic, environmental and cultural wellbeing have significant implications for the range of activities in which local authorities are engaged. In turn, this has consequences for the relationship between local government and central government. The effectiveness of the new empowerment and the prospects for further strengthening of the role of local government are critically examined. Despite some on-going tensions, and an inevitable mismatch in the balance of power between central and local government, it is argued that there is a discernible rebalancing of intergovernmental relations as a result of new legislation and central government policy settings which reflect a 'localist turn'. On the basis of developments since 2000 it may be argued that the New Zealand system of local government is evolving away from the recognised 'Anglo' model. However, further consolidation is needed in the transformation of intergovernmental relations and mechanisms that will cement a more genuine central-local government partnership.
\end{abstract}

Key words: intergovernmental relations, empowerment, New Zealand, localism.

\footnotetext{
1 The author wishes to thank an anonymous reviewer for helpful suggestions of points for clarification, and of other enhancements to the manuscript.
} 


\section{Introduction}

A virtue is often made of the independence and flexibility enjoyed by local government in New Zealand. This independence is distinctive in crossnational comparison, particularly with the sector's counterparts in Australia and the United Kingdom. With a relatively low level of central government financial transfers and high level of local funding, local government in New Zealand has enjoyed a degree of autonomy that is not found in many other jurisdictions.

This autonomy is somewhat paradoxical given New Zealand's highly centralised, unitary state. Historically, the principle of "no taxation without representation' produced an elaborate and extensive - in the eyes of some, excessive - layer of local government. To some extent this was streamlined as the result of amalgamations of local authorities in 1989 which significantly reduced the number of units of local government. However, there are still concerns that New Zealand is over-governed and that fewer units would be desirable. Adding to the paradox, and despite units of local government being so prevalent and numerous particularly up to the 1990s, no clear set of principles informs the design of local government in New Zealand. The basic features of the system were imported from the United Kingdom with colonisation in the 1840s, followed by an "unsystematic modification of the original transplants" (Bush 1980, p. 232) to address practical needs. In a similar vein, Palmer and Palmer argue that pragmatism, and a resistance to central government power by the settlers of British and European descent in the latter half of the nineteenth century, characterised thinking about the nature of local government in New Zealand. A more coherent vision, they argue, is still lacking, despite significant new legislation passed in 2002 that gave local government a new power to promote social, economic, environmental and cultural wellbeing.

Local government really started life as a practical and operational contrivance lacking any fundamental constitutional conception. It is a defect from which we still suffer (Palmer and Palmer 2004, p. 247).

The purpose of this article is to examine and analyse contemporary intergovernmental relations and the new statutory framework reflected in the 2002 legislation. Based on this analysis it is possible to delineate the underlying constitutional conception of local government embodied in the relationship. Subsequently, it may be possible to begin to remedy the defect to which Palmer and Palmer have referred, namely, the predominance of a pragmatic approach over a principle-based approach to the constitutional conception of local government.

First, the constitutional status of local government in New Zealand is outlined, with a focus on the implications of this status for the classification of New Zealand's local government in the 'Anglo' model - one of three such models that have been identified in a typology of local government 
systems in western industrialised countries. Three key features of current intergovernmental relations in New Zealand are then addressed, namely, the establishment of a central-local government forum, the new power to promote community wellbeing and associated provisions for long-term community planning, and efforts by central government to engage in local authority planning processes. It is argued that these cumulatively constitute a distinctive model of empowerment of local government if they reach their full potential. However, while there are many positive aspects to the new architecture of intergovernmental relations, a number of unresolved tensions remain, reflecting contradictions in the discourse of partnership and fault-lines in the foundations of the model of empowerment. The final part of the article argues that satisfactory resolution of these tensions and clear recognition, through some constitutional or quasi-constitutional mechanism, of the importance of local government will produce a more genuine partnership and empowerment. As a consequence, a different model of intergovernmental relations is increasingly likely to emerge, which, in turn, has implications for the classification of the New Zealand system of local government.

\section{The constitutional status of New Zealand local government}

New Zealand does not have a single written constitution but rather a number of quasi-constitutional statutes, including the Constitution Act 1986, and unwritten constitutional conventions. There is no reference to the existence of, or protection for, a system of local government (Palmer 1993). An ordinary statute, the Local Government Act 2002, and prior to that the Local Government Act 1974 and its predecessors, provide for the existence of local government.

Local government in New Zealand has historically shared features in common with other countries located within the 'Anglo' group of local government systems. Nations which are included in this group are those in which local government is a 'creature of statute', albeit with a significant degree of autonomy from central government at least in terms of day-to-day activities (Hesse and Sharpe 1991; Goldsmith 1996). Local councils in New Zealand, for example, have considerable choice in the form of their decision-making (such as committee structure and number of meetings), and in the activities in which they become involved. Through legislation central (national) government regulates some aspects of local government decision-making (such as open government legislation), and can impose certain requirements where it provides funding to local councils.

In the case of New Zealand, funding from central government comprises a much smaller proportion of local government revenue than in some other countries that belong to the Anglo group where there are more substantial central government revenue transfers. In New Zealand in the year ended 30 June 2006, the local government sector's income was \$NZ5.4 billion ( $£ 2.17$ billion). Fifty-six percent of this came from rates (property tax), while just 
12.7 percent came from central government grants and subsidies. Other sources of revenue include investment income (5.7 percent), regulatory fees and fines (5.2 percent), and other miscellaneous sources (approximately 20 percent).

The Anglo group is one of three broad types of local government systems, the others being the 'Franco' group and the 'North and Middle European' group (Hesse and Sharpe 1991). The Franco type has constitutional status although service delivery is delegated to other agencies. The North and Middle European group is characterised by similar central-local relations to the Anglo group but:

\begin{abstract}
... in contrast to the Anglo form, equal emphasis tends to be placed on local democracy per se (emphasis in original). In other words, local government is commonly granted a general functional competence over and above specific statutory powers. In this respect, the North and Middle European type is the most overtly decentralist of the three ... (Hesse and Sharpe 1991, p. 607).
\end{abstract}

In Hesse and Sharpe's analysis of twenty western industrialised countries (which includes Australia but not New Zealand), the North and Middle European group is the largest and includes countries outside Europe (for example, Japan). On the basis of their analysis they predict that this model may be the model of the future. This raises the question of whether significant developments in central-local relations in New Zealand since a change in government at the end of 1999 from a conservative government to centre-left Labour-led coalitions, provide a foundation for a future transition of the New Zealand local government system into the North European group.

Hesse and Sharpe's typology is based on an earlier one that distinguishes between legal localism and political localism (Goldsmith 1996). Legal localism - typically found in northern Europe - is "local self-government, incorporated into the constitutional and/or procedural arrangements ... which effectively ensures a role for elected local government in the affairs of state" (Goldsmith 1996, pp. 191-92; see also Briffault 1990). Political localism - associated with southern European states - reflects a strong communitarian emphasis on representation of territorial interests (Goldsmith 1996, pp. 187-191). There is commonly a strong interpenetration of central and local tiers of government, with party and political linkages ensuring that local interests are heard at the centre. New Zealand's system of local government reflects elements of legal localism but its conformity to that model is arguably weak given the lack of explicit constitutional recognition of local government.

Following the reforms of 1989, which involved widespread, centrally imposed amalgamations of local authorities, academic and other commentators highlighted the weak constitutional status of local government in New Zealand. At this time there were calls for stronger 
constitutional protection (see, for example, Jansen 1992). While the fortunes of local government have historically been subject to the whim of national governments, initiatives since 2000 under three successive Labourled administrations mean that formal constitutional protection may not be so essential going forward as it might have been. ${ }^{2}$

It is timely to enunciate some principles that can underpin an appropriate constitutional conception of local government. Writing somewhat presciently nearly three decades ago, Bush (1980, p. 240) opined:

There is a growing discrepancy between the professed claims of Government to vest its junior partner with augmented powers and its own infiltration into the same realm. Whether the accurate image is of being arm-in-arm or of being led by the nose, a changing pattern of central-local relations is undoubtedly emerging. Interaction will be more frequent and intimate, with central probes to ascertain the point at which resistance is offered. ... [T] he era of intermittent and unplanned contacts is departing. 'Integrated planning' is the flag fluttering at the masthead and this alone precludes a laissez-faire approach.

As has become evident recently in the case of the partnership between central government and the community and voluntary sector, the potential for a relationship breakdown remains a possibility when there is a lack of clarity about the nature of the partnership and the status of the junior partner. Recently, the Community Sector Taskforce, an umbrella organisation representing the community and voluntary sector, accused the government of paternalism towards the sector and claimed that the sector is being disempowered by government actions.

In 2001 central government released the Statement of Government Intentions for an Improved Community-Government Relationship (Clark and Maharey 2001) that formed the basis of further developments designed to forge a genuine partnership. The Statement expresses in written, published form an agreed set of understandings between representatives of the two parties. ${ }^{3}$ However, the Community Sector Taskforce has questioned the prospects for such a partnership and claimed that the government "cannot handle sector aspirations for an appropriately independent future" (Community Sector Taskforce 2007, n.p.).

It is vital that central-local government relations go from strength to strength, under current and future national governments, and do not give rise to accusations of paternalism and insincere rhetoric about partnership. Later in this article consideration is given to options for greater protection

\footnotetext{
2 It remains the case, however, that a Labour-led government in New Zealand could embark on reforms that fundamentally weakened the sub-national tier of government, and indeed, the fourth Labour government's reforms of local government in 1988-89 were very unpopular in the sector and were justifiably viewed as being imposed in a top-down manner. 3 In the United Kingdom there is a similar agreement between government and the voluntary and community sector that aims to improve their relationship for mutual advantage and community gain. See http://www.thecompact.org.uk
} 
for the place of local government within the system of intergovernmental relations, but first the focus turns in the next section to the matter of public policy discourse and the evolving status of local government in the wider governance arrangements since the change of central government in 1999.

\section{The new phase in intergovernmental relations post 1999}

A change of government in New Zealand at the end of 1999 resulted in the formation of a Labour-Alliance coalition, and both parties had strong manifesto commitments to strengthening local government. A new phase in intergovernmental relations thus emerged, evidenced by three key features: the establishment of a central-local government forum in 2000; the new power to promote wellbeing and the associated long-term community planning process mandated in the Local Government Act 2002; and a new expectation that central government agencies will be engaged in the identification, monitoring and achievement of community outcomes. ${ }^{4}$ Together they (potentially) signify a qualitatively different reconfigured relationship between the two tiers of government.

\section{Central-local government forum}

In March 2000 the Central-Local Government Forum was established to ensure regular meetings between the political executive of Parliament (the Prime Minister and other senior Cabinet Ministers) and senior local government leaders. The Prime Minister and the President of Local Government New Zealand, the peak body representing New Zealand's 85 units of local government, jointly chair the Forum. This was a significant development as the two leaderships had not met in such a manner and historically local government was often either largely overlooked by central government in policy development, or changed at the whim of central government reformers without adequate consultation. The Forum meets twice yearly and is recognised as giving both central and local government participants an enhanced appreciation of one another's perspectives and pressures.

The establishment of the Forum reflected growing acknowledgement by central government of the contribution of local government, and also increasing dependence on local government, in achieving government outcomes. Participants and observers report a concomitant mutual understanding and trust growing between the two parties. For example, Burton (2006, n.p.) comments:

Given the vast array of local government functions, there are a number of Ministers as well as government departments and agencies who need to be aware of the role and function of local government, and the

\footnotetext{
${ }^{4}$ Community outcomes are medium and long term goals or desired end-states - "the things that the community thinks are important for its wellbeing" (New Zealand Society of Local Government Managers et al. 2003, p. 39) - that are identified by communities through a consultative process facilitated by local government at least once every six years (see section 91 of the Local Government Act 2002).
} 
decisions that need to be made on a day-to-day basis. I am confident the ten meetings held to date have given both central and local government participants a valuable understanding of the pressures facing each other's respective sectors. As a result of this developing relationship, there is a good deal more trust between central and local government. This is already paying dividends.

Likewise, writing of developments at the beginning of the present decade, Wallis and Dollery (2001, pp. 556) observe: "The issue of central-local trust therefore appears to have replaced the issue of accountability as the primary focus of the local government policy debate." Building trust between local government and the new Labour-led government was an important task given the legacy of the earlier fourth Labour government (1984-1989), which imposed radical amalgamations over the course of a very short but intense period of reform in 1988-89, and also after nearly a decade of conservative administrations which were characterised by, at best, benign neglect.

\section{The power to promote community wellbeing}

Early on in its first term (1999-2002) the Labour-led government introduced a review of local government legislation that produced further shifts in intergovernmental relations, most notably the new Local Government Act 2002 with its broad empowerment of, and new purpose for, local government. Section 10 of the Act sets out the purpose of local government as follows:

to enable democratic local decision-making and action by, and on behalf of, communities; and

to promote the social, economic, environmental, and cultural wellbeing of communities, in the present and for the future.

The overall aim of the Act as set out in section 3 provides for local authorities:

to play a broad role in promoting the social, economic, environmental and cultural wellbeing of their communities, taking a sustainable development approach.

This mandates a much broader focus than local government's traditional concerns of the 'three Rs': rats (that is, public health), rubbish, and roads. However, it is also clear that empowerment is for a specific purpose, namely, sustainable development. While local government has considerable flexibility to decide what activities it will undertake, these activities must be consistent with the purpose of local government. The change was particularly significant for regional councils, which historically have had a much narrower range of activities - mostly regulatory roles linked to resource management. However, it was also recognised that it 
was unlikely that any local authority (regional or territorial ${ }^{5}$ ) would have the community mandate or funds to venture into significant new activities.

Section 12 of the Act outlines the powers of local authorities, giving them "full capacity to carry on or undertake any activity or business, do any act, or enter into any transaction". Local authorities have full rights, powers and privileges for the purpose of performing their role, subject to the provisions of the Local Government Act, any other statute and general law. Territorial authorities must exercise their powers wholly or principally to benefit the district while a regional council must exercise its powers wholly or principally to benefit a significant part or more of its region.

Notwithstanding a popular view that the 2002 Act took local government away from its core business (primarily roads, water, stormwater, waste water, waste disposal), in fact local government has undertaken a broad array of functions since at least the mid 1970s, following the enactment of the Local Government Act 1974. However, the earlier Act embodied a prescriptive rather than empowering approach to the range of functions that local government could undertake. As Palmer and Palmer (2004, p. 230) explain:

The approach in the old Act was: before local authorities did anything they needed to check to see that they were empowered to do it. For example, section 663 reassured they that were empowered to install clocks. Section 659 confirmed they could sell firewood.

The sustainable development emphasis of the 2002 Act represents a significant shift in thinking about the role of local government, and reflects the understanding that wellbeing encompasses (at least) four significant domains: environment, economy, social and cultural aspects. Thus, for local government to contribute to the goal of sustainable development it was essential that it be empowered to address development as it impacts on all dimensions of the wellbeing of current and future generations.

\section{Central government engagement in local authority community planning processes}

Local authorities are required to address how they work together with other territorial and regional organisations, central government, and nongovernmental organisations to further their community outcomes and priorities. Central government is a particularly significant stakeholder in that its policies and resources have major impact on community wellbeing. In addition, central government agencies collect data that is critical for local authority planning. Following the introduction of the new legislation Cabinet recognised that central government agencies would increasingly

\footnotetext{
${ }^{5}$ In New Zealand, local government is made up of two main types of authority: regional councils and territorial authorities. The latter, district or city councils, are grouped into regions. There are also four unitary authorities that perform both regional council and territorial authority functions.
} 
need to contribute to the achievement of community outcomes. In 2004 Cabinet directed a central government agency, the Department of Internal Affairs (which has responsibilities for local government policy and also for community development services), to take a lead role in facilitating central government engagement in community outcomes processes (COPs).

While Cabinet intended that central government agencies would work in partnership with local authorities and communities to achieve mutually agreed outcomes, it also noted that the regional level was an appropriate focus for central government participation in COPs. Because there were already existing regional networks and initiatives, it would be less onerous for central government agencies than district level engagement, and the government's policy was to foster regional development. However, regional and territorial councils have different roles in many cases and it is not feasible for central government agencies to deal only with regional councils. For example, in relation to an issue such as housing affordability, which is an issue for many territorial authorities, progress towards outcomes will require involvement at the territorial level of a number of central government agencies. Some central government agencies have been proactive in engaging with local government while others have been tardy or unwilling. ${ }^{6}$

\section{The emergent new model of empowerment}

Together these three developments signal a reconfiguration of intergovernmental relations, referred to by a number of commentators as the 'new local governance'. A key component of this new governance relationship is its incorporation of a 'community, spatial or place perspective on public policy and service delivery' (Reddell 2002, p. 53). Reddell notes that, with increasing research evidence of uneven social and economic development as a result of globalisation, concern about spatial or locational disadvantage has resulted in a focus on regions and local communities. In New Zealand, community-based and regional initiatives have been promoted in a range of social and economic policy domains (see, for example, Casswell 2001).

While there is growing momentum for some modifications to some of the statutory requirements, and some greater central government policy leadership, the localist impetus is likely to remain powerful and not simply at a rhetorical level. The current emphasis on community planning is also prompted by concerns about the 'democratic deficit' (reflected in citizen disengagement from political processes, in particular voting, at the local level), and the need to enhance the responsiveness of local government (Cheyne 2006). It is also suggested that arresting the continuing decline in

\footnotetext{
6 The Ministry of Social Development appears to have been one of the more proactive through its development of Regional Social Policy capability and through producing a comprehensive resource for staff (Ministry of Social Development 2005).
} 
voter turnout at local elections will only be achieved if local government has greater responsibilities.

In order for local government to exercise greater responsibilities some of the evident tensions in the new intergovernmental relations will need to be resolved. Particular tensions are associated with the financing arrangements for local government given its broad power to promote wellbeing and the emphasis on its sustainable development role; lack of alignment between central and local government planning processes as a result of different political priorities and central government inertia; and the bounded power of general competence.

\section{Financing arrangements}

Enhanced empowerment in the 2000s has become a double-edged sword for local government in New Zealand. The neo-liberal economic policies of the 1990s resulted in tight fiscal settings and under-investment in public infrastructure which, when combined with community outcomes processes that elevated community expectations about services, infrastructure and quality of life, have placed significant pressures on local government budgets. Increasingly, questions are being raised about the ability of local government (given its traditional financing arrangements - primarily property tax or 'rates') to fund necessary expenditure on infrastructure and services (Shand, Cheyne and Horsley 2007). The alternative is increased transfers of funding from central government, especially where there is a national interest in having consistent and certain standards of service or infrastructure. However, to the extent that central government will require accountability for funding devolved to local government, this has implications for local government autonomy as alluded to by the former Minister of Local Government (Burton 2006, n.p.):

The ability of local authorities to provide acceptable levels of infrastructure into the future is uneven. This raises questions about whether and when central government should assume some responsibility for funding local infrastructure, and the relationship between such funding and the local expenditure priorities of each council.

\section{Lack of alignment between central and local government planning processes}

While the new community planning process in the LGA 2002 is intended to strengthen the community governance role of local authorities, the desired co-ordinated planning and alignment of central government and community outcomes has been slow to emerge. The planning cycle of central government is based primarily on an annual budget, Statements of Intent between Ministers and chief executives of government departments, and 
the three yearly electoral cycle. ${ }^{7}$ There is a growing emphasis on 'outcomes-focused' management, which has generated a plethora of strategic planning documents. But, crucially, these are fundamentally driven by Cabinet policy (which reflects the policies of other parties in government and Labour's support agreements with these parties). The planning cycle of central government is not aligned with local authority planning cycles and processes, yet central government agencies are expected to contribute to achievement of community outcomes. In some policy areas, the mismatch has become evident and there are initiatives underway to improve alignment. Improved alignment would tend to be sought through ensuring that local government plans recognise central government political priorities, ${ }^{8}$ however, it can also be sought through modifications to central government policy goals (for example, as set out in Statements of Intent). Further research is needed to identify whether there is in fact a two-way process of adjustment of outcomes. To the extent that there is no scope for dialogue between the two tiers of government about central government's policy settings and outcomes, there is a risk that the notion of a community-driven planning process will be compromised. However, community planning is always conducted within the parameters of a nation-state that has international obligations and these are likely to become more pressing (particularly in relation to climate change).

\section{Limitations on local government autonomy}

The new Act does not explicitly provide a full 'power of general competence' - the legal term empowering local government to undertake any function that is not expressly precluded by law or given exclusively to another body - although Palmer and Palmer (2004) consider that the new Act moves closer to such a power, and both many in the local government sector and many commentators refer to the new power to promote wellbeing as a power of general competence.

Thus while technically, or de jure, local government does not have a power of general competence, it would appear to have such a power de facto. However, that power is also widely acknowledged as being delimited in a number of ways. At an early stage in the development of the Local Government Act 2002 Cabinet agreed that the proposed empowerment of local government would be subject to provisions to ensure clear accountability to communities and open governance. It was noted that, as well as granting broader powers to local authorities, central government should take a greater interest in the exercise of these powers and in local authority performance. Thus there are some provisions for central government to intervene in local government, such as the power to initiate a

\footnotetext{
${ }^{7}$ A Statement of Intent (not to be confused with the Statement of Government Intentions between the government and the community and voluntary sector discussed earlier) identifies, for the medium term, the main features of intentions regarding strategy, capability and performance. After being finalised, the Statement of Intent is tabled in Parliament.

${ }^{8}$ One example is land transport policy where the lack of recognition of the goals of the New Zealand Transport Strategy in regional and district council land transport programmes was highlighted in the Next Steps review (Minister of Transport 2007).
} 
Ministerial Review (Office of the Minister of Local Government 2000). However, this is used extremely rarely.

Rather than prioritise 'hard' powers of intervention, less direct influence has been wielded through the use of principles-based statutory provisions in the Act that guide behaviour. These principles cover many aspects of local government's activities, including governance, decision-making and consultation, and potentially open up the sector to legal challenge. More immediately they impose significant new standards, although there is still considerable emphasis on council discretion in the application of principles.

Despite the intention of empowerment, the 2002 Act fell short of a full retreat from prescription. From when it first appeared as a Bill, a wide range of commentators have drawn attention to the cumbersome requirements of the Act, particularly in relation to the statutory planning and accountability requirements (see, for example, McGregor, O'Reilly and Smith 2002). The consultation and decision-making provisions are particularly onerous. As Palmer and Palmer (2004, p. 250) observe:

\begin{abstract}
Having decided to empower local government ... the Act then tends to restrict the exercise of the powers granted by tying them up in a host of prescriptive and procedural requirements that may prove cumbersome and expensive to comply with on the part of local authorities. It almost appears as if, having given local government greater powers, it was necessary to wrap them up in such a way that they could not be exercised too easily.
\end{abstract}

The detail in the legislation was greater than many anticipated, suggesting that central government has imposed its will on the sector, thus maintaining the greater share of power in the overall relationship. But significant discretion is also given to - and exercised by - local government (for example in deciding how to conduct consultation).

Concerns about the imposition of central government requirements on local government - the so-called 'unfunded mandate' - have led to efforts to monitor and streamline the impacts on councils. Local Government New Zealand has identified a range of different impositions, including intended devolution and unintended devolution (LGNZ 2005). The Department of Internal Affairs recently published guidelines for central government agencies when developing policy that impacts on local government (DIA 2006). As yet there is no evidence of the impact of these guidelines, although new central government strategies continue to emerge in the achievement of which local government is heavily implicated. ${ }^{9}$

\footnotetext{
9 A recent example is the New Zealand Energy and Efficiency Conservation Strategy released in October 2007 (Minister of Energy 2007).
} 


\section{Empowerment versus centralism: contradiction and paradox in the model}

In mid 2006 local councils published their first ten-year plans (a new requirement of the Local Government Act 2002, making transparent their planned expenditures and revenue needs over the period from 2006 to 2016. Public concern about rates increases intensified, as the magnitude of local government's funding requirements became clearly visible. Although not necessarily the case, the empowerment of local government in the 2002 Act is often seen by disgruntled ratepayers as the cause of increased local government expenditures and hence rates. Public concern about rates increases led central government to set up a panel to conduct an independent inquiry into local government funding. ${ }^{10}$

The panel, which reported in August 2007, confirmed that rates were an appropriate source of funding but recognised that they were becoming unaffordable - particularly in the Auckland region - because of infrastructure spending requirements. Therefore, the panel, as directed by its terms of reference, considered other sources of funding including income tax, goods and services taxes and environmental taxes. It did not support local or regional income taxes, GST, bed taxes or general revenue sharing by central government. However, it recommended an increase in the current local authority petroleum tax and further consideration of an environmental levy on international visitors as a means of meeting the environmental costs imposed by those visitors and thus of maintaining high environmental standards. It also recommended greater central government transfers (funding given by central government to local government). It noted that the existing system of land transport funding generally worked well as a partnership between central and local government and should be replicated in the funding of water infrastructure. Central government should provide increased funding for infrastructure for water supply, wastewater and stormwater (that is, the 'three waters') through a new Infrastructure Equalisation Fund.

As part of its inquiry, the panel received nearly a thousand submissions and met with the public and with the local government sector. Submissions and presentations from the local government sector often sought increased and new transfers from central government, although a large number also acknowledged that new funding from central government would inevitably lead to greater control by central government in order to ensure accountability for the use of taxpayer funds. It has been the experience of the local government sector in New Zealand (and arguably in many other countries though not necessarily always) that central government funding comes with strings attached. Certainly, the contractualism that emerged in the 1990s following the public sector reforms inspired by New Public Management (Boston et al. 1996) highlighted the need for financial and

\footnotetext{
10 The report of the inquiry was completed in August 2007. Further information and the final report are available at www.ratesinquiry.govt.nz
} 
other accountability by organisations receiving funding from central government to deliver public services. The same is true for funding channelled to local government (for example, for road works). Central government-imposed compliance costs in demonstrating accountability are often very substantial, unresponsive to local situations and preferences, and in conflict with 'common sense'.

While central government benevolence in the form of grants and subsidies was obviously an attractive solution, for many a more serious option is to achieve a more genuine partnership between central and local government so that central government is aware of the implications of new central government policy initiatives on local authority budgets. In particular, new environmental and health standards (for example, drinking water standards), and central government policies to increase international tourism could impose significant costs on rural communities with a small number of ratepayers. A common theme in submissions from the local government sector was the need for enhanced communication between the two sectors. The central-local government forum discussed earlier is one initiative that can contribute to improved mutual understanding.

As intergovernmental relations develop and the role of local government is ostensibly reinforced, there is a growing challenge to establish the necessary balance between local discretion, local accountability and national consistency and standards. This is particularly acute in the area of environmental policy. The Resource Management Act 1991 set in place a regime of devolved environmental management, although with provision for additional national environmental standards and national policy statements. Only one national policy statement was mandated (a national coastal policy statement) and in the 1990s there was neither political will, nor much momentum elsewhere, for national policy statements. More recently there has been a growing consensus that additional policy statements are needed as well as many more national environmental standards; however, progress is glacial. To no small extent the slow progress reflects bureaucratic inertia, but reticence on the part of central government to mandate policy and standards is often a Trojan horse for persistent adherence to the still-powerful market-led model of planning; thus it is not so much endorsement of local decision-making as it is antipathy toward state intervention.

\section{New Zealand's place in the Anglo model}

The introduction of the new power for New Zealand's local authorities to promote social, economic, environmental and cultural wellbeing was arguably influenced by the British Local Government Act 2000 which placed a duty on local authorities in England and Wales to prepare 'community strategies' for promoting or improving the economic, social and environmental wellbeing of their areas, and contributing to the achievement of sustainable development in the United Kingdom. It also 
gave local authorities broad new powers to improve and promote local wellbeing as a means of helping them to implement those strategies. The Local Government in Scotland Act 2003 introduced similar community plans into Scottish local government.

Implementation of these new powers highlighted the need to consider the financing of local government and this led to the establishment of the Lyons Inquiry into Local Government in July 2004. In September 2005 the inquiry was broadened to encompass local government's role and function. The responsibilities of local government for developing community strategies focused attention on what the Lyons Inquiry termed the 'placeshaping' role of local government and the need to "rebalance the relationship between centre and locality" (2007, p. i). 'Place-shaping' is defined as "the creative use of powers and influence to promote the general wellbeing of a community and its citizens". It includes such things as fostering local identity; regulation of harmful activities; community representation; promoting local economic development; identifying and responding to local needs and preferences; and building social cohesion. The report explicitly argues for the relevance of place (Lyons Inquiry 2007, p. 2):
As our understanding of the multi-faceted nature of social and economic problems grows, and as our aspirations to solve them and to govern uncertainty and diversity increase, the arguments for a local role in determining the actions of government and the provision of public services are becoming stronger. In addition, economic analysis continues to identify local factors and institutions as important influences on economic change and growth

As such the report is situated within the 'new localist' paradigm (see Pratchett 2004 for a brief overview of this paradigm). While there are some significant differences between local government in the United Kingdom and New Zealand, with the latter having much greater autonomy through its lack of dependence on central government funding, the Lyons Report has highlighted the importance of local government's place-shaping role. The changes in the United Kingdom as a result of the local government modernisation agenda, and those in New Zealand, suggest that these local government systems may be evolving to become more like the Northern European model as posited by Hesse and Sharp. However, McKinlay (2002) highlights the differences between local government in New Zealand and its counterparts in Australia and the United Kingdom. In Australia and the United Kingdom there is generally a much more topdown relationship, with local government being relatively powerless and subject to the rules and decisions of a higher tier of government (central government in the United Kingdom, the state or federal government, depending on the policy domain, in Australia).

For New Zealand, the prospect of a transition towards the North European model will be dependent on the development of further institutional 
features to consolidate and complement evolving intergovernmental relations. One approach would be to introduce an entrenched provision into those parts of the Local Government Act that deal with the existence of the Act and the purpose of local government. This would mean that the relevant statutory provisions could not be changed without meeting a certain threshold of parliamentary support (say, 65 percent). Another approach would be to adopt a charter of local self-government, or public Statement of Government Intentions regarding the relationship with local government, along the lines of the document signed between the government and the community and voluntary sector in 2001 (discussed earlier).

\section{Conclusion}

Writing soon after the major reorganisation of local government imposed by central government at the end of the 1980s, Jansen (1993, p. 6) opined that "local government autonomy is rather more pious hope than reality". However, reflecting on the experience of the 1990s, Wallis and Dollery (2001) noted that the impact of reforms reflected the predominance of the 'activist' view of local government over the 'minimalist' view. In the minimalist view, the proper role of local government is the provision of local public goods and local government should not engage in the provision of private goods and services. The activist view encourages local authorities to engage with their communities to identify the community's preferred social and economic outcomes and to work actively towards these (Wallis and Dollery 2001, pp. 546-549).

Nearly twenty years on from the 1989 reorganisation and legislative amendments, and nearly a decade on from the establishment of a new phase in intergovernmental relations, the New Zealand system of local government has achieved a new status in its relationship with central government and the political executive (Prime Minister and Cabinet). Although regarded as belonging to a group of countries that comprise the 'Anglo' model, this new status arguably distinguishes it from others in that group (for example, Australia and the United Kingdom). The Central-Local Government Forum, new statutory provisions for long-term community planning, and central government engagement in the planning processes have altered local government's status - though not necessarily irrevocably. The gains for the two parties may be lost in the future with a different central government executive, and there is still a lack of appropriate balance in the power relationship. The imbalance in, and contingent nature of, the current relationship can be redressed through a more explicit constitutional or other recognition of the vital role of local government in counterbalancing the weight of the sovereign state.

Prior to the change of government in 1999, Reid (1999, p. 181) argued:

The challenge for local government in New Zealand is whether or not the nation's tradition of strong centralism will continue to dominate 
policy debate to the detriment of local democracy and effective service delivery, or whether, with the adoption of new frameworks, effective co-governance relationships can be established.

Notwithstanding the broad empowerment provided by the Local Government Act 2002, the fact remains that all local government's powers are derived from statutes passed by Parliament. The Central-Local Government Forum, which first met in 2000, has operated for nearly three parliamentary terms. Constitutional protection of the functions and powers of local government would consolidate this evolving partnership and ensure its continuity at a possible future time when central-local relations might not be so warm or when political management at the centre becomes overly centralising. When central-local relations are positive it is less obvious that such protection is needed. However, it is precisely at a time of enhanced status for local government that it is important to clearly establish its legal competence, and secure the gains that have been made in the partnership between central government and a strong, independent local government sector.

\section{References}

Andrew, C and Goldsmith, M 1998, 'From local government to local governance and beyond?' International Political Science Review vol. 19, no. 2, pp. 101117.

Advisory Group on the Review of the Centre 2002, Report of the Advisory Group on the Review of the Centre, State Services Commission, Wellington.

Boston, J, Martin, J, Pallot, J and Walsh, P 1996, Public Management. The New Zealand Model, Oxford University Press, Auckland.

Briffault, R 1990, 'On localism: Part II Localism and legal theory', Columbia Law Review vol. 90, no. 2, pp. 346-454.

Burton, M 2006, Speech notes for address to Local Government New Zealand workshop for newly elected mayors, 28 February, <http://www.beehive.govt.nz/ViewDocument.aspx?DocumentID=25048>.

Burton, M 2007, Speech to the New Professionals Network IPANZ, 20 February, <http://beehive.govt.nz/Print/PrintDocument.aspx?DocumentID=28445>.

Bush, G 1995 Local Government and Politics, Auckland University Press, Auckland.

Casswell, S 2001, 'Community capacity building and social policy - what can be achieved?' Social Policy Journal of New Zealand no. 17, pp. 22-35.

Cheyne, C 2006, 'Local Government' in R Miller (ed.), New Zealand Local Government and Politics, Oxford University Press, Melbourne, pp 285-295.

Clark, Rt Hon. H and Maharey, Hon. S 2001, Statement of Government Intentions for an Improved Community-Government Relationship, New Zealand Government, Wellington.

Cowell, R 2004, 'Community Planning: Fostering Participation in the Congested State?’ Local Government Studies vol. 30, no. 4, pp 497-518. 
Cribb, J and Berthold, T 1999, Roles of Central and Local Government in Joint Problems, Working Paper No. 1, SSC, Wellington.

Denters, B and Rose, L E (eds) 2005, Comparing Local Governance. Trends and Developments Houndmills, Basingstoke, Palgrave Macmillan.

Department of Communities and Local Government 2006, Strong and Prosperous Communities. The Local Government White Paper, <http://www.communities.gov.uk/localgovernment/currentagenda/strongpro sperous/>.

Department of Internal Affairs 2006, Policy development guidelines for regulatory functions involving local government, <http://www.dia.govt.nz/diawebsite.nsf/wpg_URL/Resource-material-OurPolicy-Advice-Areas-Policy-development-guidelines-for-regulatoryfunctions-involving-local-government?OpenDocument>.

Geddes, M 2006, 'Partnerships and the Limits to Local Governance in England: Institutionalist Analysis and Neoliberalism' International Journal Of Urban and Regional Research vol. 30, no. 1, pp. 76-97.

Goldsmith, M 1996, 'Normative Theories of Local Government: A European Comparison' in D King and G Stoker (eds), Rethinking Local Democracy, Macmillan, Houndmills, pp. 174-192.

Goss, S 2001, Making Local Governance Work. Networks, Relationships and the Management of Change, Palgrave, Houndmills, Basingstoke.

Hess, J J (ed) 1991, Local Government and Urban Affairs in International Perspective. Analyses of Twenty Western Industrialised Countries, Nomos Verlagsgesellschaft, Baden-Baden.

Hess, J J and Sharpe, L J 1991, 'Local Government n International Perspective, in Hess, J J (ed.), Local Government and Urban Affairs in International Perspective. Analyses of Twenty Western Industrialised Countries, Nomos Verlagsgesellschaft, Baden-Baden, pp. 603-621.

Lyons Inquiry into Local Government 2007, Place-shaping: a shared ambition for the future of local government, <http://www.lyonsinquiry.org/>.

Jansen R 1993, New Zealand Local Government Changes in the 1980s: Reform or Restructuring? Unpublished $\mathrm{PhD}$ thesis, University of Waikato, Hamilton.

McGregor D, O'Reilly L and Smith M 2002, 'Time for a reality check' New Zealand Local Government vol. 38, no. 4 (April), pp. 28-29.

McKinlay, P 1998, Devolution, Partnership or Ad Hocism? The Relationship between Central and Local Government, <www.mdl.co.nz/library/librarydocs/public_mmt/Devolution_1998.pdf>.

Memon, P A and Thomas, G 2006, 'New Zealand's Local Government Act: A Paradigm for Participatory Planning or Business as Usual?', Urban Policy and Research vol. 24, no. 1, pp. 135-144.

Minister of Energy 2007, Energy strategy delivers sustainable energy system. Speech notes for launch of NZ Energy Strategy. Grand Hall, Parliament Buildings, Wellington, 11 October, <www.beehive.govt.nz/Print/PrintDocument.aspx?DocumentID=30955>

Office of the Minister of Local Government 2000, Review of the Local Government Act : Paper 2 - Purpose and General Powers of Local Government, $<$ http://www.dia.govt.nz/Pubforms.nsf/wpg_CabinetPapers_LGAREV?Ope nView $>$

Palmer, K A 1993, Local Government Law in New Zealand, Law Book Co., Sydney. 
Palmer G and Palmer, M 2004, Bridled Power. New Zealand's Constitution and Government, Oxford University Press, Melbourne.

Pratchett, L 2004, 'Local Autonomy, Local Democracy and the 'New Localism', Political Studies, vol. 52, no. 2, pp. 358-375

Reddel, T 2002, 'Beyond Participation, Hierarchies, Management and Markets: 'New' Governance and Place Policies', Australian Journal of Public Administration, vol. 61, no. 1, pp. 50-63.

Reid, M 1999, 'The central-local government relationship: the need for a framework? 'Political Science vol. 50, no. 2, pp. 165-181.

Richardson, M 2005, Reflections on What was Achieved in the Local Government Act 2002 <http://www.waikato.ac.nz/igci/pucm/Linked\%20documents/Mike\%20Rich ardson\%20Response.pdf>.

Shand, D, Cheyne, C and Horsley, G 2007, Funding Local Government. Report of the Local Government Rates Inquiry, Local Government Rates Inquiry, Wellington.

Wallis, J and Dollery, B 2001, 'Local government policy evaluation in New Zealand: radical reform and the ex post emergence of consensus or rival advocacy coalitions' Public Administration vol. 79, no. 3, pp. 533-560.

Wilson, V and Salter, J 2003, A Guide to the Local Government Act 2002, Brookers Ltd, Wellington. 